\title{
THE POSSIBILITIES OF COLLECTIVE CHOICE: ARROW'S THEOREM, ARTICLE I, AND THE DELEGATION OF LEGISLATIVE POWER TO ADMINISTRATIVE AGENCIES
}

\author{
WILIIAM T. MAYTON*
}

The lawmaking process established by the Constitution's first article mcludes a regard for democracy, rationality, and decisiveness. How this is so, and how these matters are suspended in a fine balance within Article I, is revealed by Arrow's theorem. This theorem, for which Kenneth A. Arrow received the Nobel Prize in 1972, is a proof about the possibilities and limitations of modes of collective choice. ${ }^{1}$

A point of entry into what Arrow's theorem says about Article I is an examination of a certain first impression. This impression is that as the theorem proves the impossibility of rational (that is, consistent and coherent) social choices by voting systems turning on majority rule, it shows an inability on the part of democratic processes to achieve consistent and coherent social pohicy. But such rational policy, the theorem also showed, might be achieved by means of a dictator. ${ }^{2}$

Consequently, the theorem is seen as supporting legislative arrangements alternative to those established by Article I. In particular, the theorem is seen as supporting the transfer of legislative powver out of the democratic politics of Article I, where rationality is thought to be impossible, to places where it is possible. The modern administrative agency, operating according to a condition of dictatorship, is thought to be such a place. ${ }^{3}$ In this way, Arrow's theorem is taken as proving the intuition-about achieving consistent and coherent social policy through technocratic governance- - that has long been offered as a justification for the administrative state. ${ }^{4}$

* Professor of Law, Emory University School of Law; J.D. 1972, Columbia University. I thank Professors Howard Abrams and Jon Macey for their insightful comments on the substance of this article.

1. K. Arrow, Soclal Choice and Individual Values (2d ed. 1963)

2. Id. at 59 .

3. See D. Mueller, Public Choice 189 (1979); Mashaw, Prodelegation: Why Administrators Should Make Political Decisions, 1 J.L. Econ. \& ORGanization 81, 98-99 (1985).

4. See M. Weber, The Theory of Social and Economic ORganization 324-423 (1964). The classic New Deal exposition of the faith in technocratic rationality is found in J. LANDIS, THE 
In this context, transferring legislative power to administrative agencies has straightforwardly been seen as a trade-off of democratic values for the rationality and decisiveness of agencies. Viewed in these terms, the debate centers on whether this diminution of democratic values is worth it, whether "fundainental policy decisions in our society" should be decided "by an appointed official" or by Congress, the "body immediately responsible to the people."5

A contribution of Arrow's theorem is to widen this debate. As it sheds strong new light on the various parts of Article I-on its decision costs and checks and its so dehiberately diffused lawmaking process-it shows how rationality is induced by these parts. The way in which Article I makes that rationality possible also ordains a certain result, a certain indecisiveness in our national legislative process. Today this indecisiveness is soinetimes disparaged as "democratic paralysis." To the framers, lowever, it was a "circumspection in lawinaking" desirable enougl1 to be considered a purpose of Article I. This circumspection reflects the behef that government is neither an exclusive nor error-free way of making social choices. Consequently, a certain deliberation and care in the choices government does make is essential.

This article is about three things. The first is low rationality and a "circumspection in lawmaking" are, along with democratic values, purposes of Article I, and how these purposes are held in balance within Article I. The second is whether delegations of legislative power to agencies serve these purposes of rationality and circumspection. As constitutional law goes, these things are serious. Perliaps our Constitution is marvelous in its flexibility. Even so, it can be stretched so as to become dysfunctional, so that instead of facilitatimg American government, it impedes it. It seems to ine that in the case of expedient and careless allocations of legislative power to agencies we have reaclied that stretching poimt.

Administrative Process (1938). The creation of the Federal Trade Commission is an example of congressional faith in that rationality. Congress gave the FTC sweeping power over commercial practices on a profession of faith that trained experts would develop consistent economic policy, a body of "precedents and traditions, and a continuous policy." G. HENDERSON, THE FEDERAL Trade Commission 19 (1924).

5. Arizona v. California, 373 U.S. 546, 626 (1963) (Harlan, J., dissenting).

For a classic exposition of consensual government, see J. LOCKE, TwO TREATISES OF GOVERNMENT (P. Laslett ed. 1960). Locke wrote that:

The People alone can appoint the Form of the Commonwealth, which is by Constituting the Legislative, and appointing in whose hands that shall be. And when the People have said, We shall submit to rules, and be govern'd by Laws made by such Men, and in such Forms, no Body else can say other Men shall make Laws for them; nor can the People be bound by any Laws but such as are Enacted by those, whom they have Chosen ... . Id. at 380 . 
The third thing that this article is about is the "delegation doctrine." If one concludes, as I do, that basic choices of social policy should be made in Congress and not in the agencies, then the natural inquiry, at least for lawyers, is whether this limitation on agency power is a viable legal limitation. That is, is the delegation doctrine as it distinguishes between appropriate and inappropriate delegations of legislative power discriminating enough to be enforced by the courts?

\section{ARTICLE I AND ARRow's Theorem}

As an individual inakes choices, he can be expected to do so consistently and coherently. If an individual prefers disarmament to cold war and cold war to hot war, then we can assume that he will prefer disarmament to hot war. We cannot, however, nnake the same assumption when people make choices collectively. Suppose that a community chooses among various options. Accepting the grundnorm of democracy, that the commurity's choices should be based on the preferences of its members, then the intuitively appealing means of making those choices is by majority vote. There is inuch to be said for this ineans of collective choice: it is decisive, it is simple, and it establishes an equality among voters.

Counter to most people's intuition, this mode of collective choice will not, however, produce consistent and coherent choices as in the case of an individual. Suppose that a commumity consists of three individuals and that its choices are among options $A, B$, and $C$. Suppose that the first individual prefers $A$ to $B, B$ to $C$, and $A$ to $C$; that the second prefers $B$ to $C, C$ to $A$, and $B$ to $A$; and that the third prefers $C$ to $A, A$ to $B$, and $C$ to $B$. Counting the votes, the community prefers $A$ to $B$ and $B$ to $C$. This would seen to imply that the community prefers $A$ to $C$. But this is not so; in fact a majority prefers $C$ to $A$. As the community's choices lack consistency and coherency, these choices are also "path dependent"- that is, a particular choice can be deterinined by controlling the voting agenda. ${ }^{6}$

The fact of cyclical choices as arrived at above is referred to as Condorcet's paradox, after the Marquis de Condorcet, the French mathematician and philosopher who described this fact two hundred years ago. ${ }^{7}$ Today, Kenneth Arrow proved that Condorcet's paradox applied universally to methods of collective choice. He did so axiomatically, that is, he identified certain conditions as being essential to any fair and rational

6. See W. Riker, Liberalism Against Populism: A Confrontation Between the THEORY OF DEMOCRACY AND THE THEORY OF SOCIAL CHOICE 170-82 (1982).

7. See D. BlACK, The TheORY OF COMMITTEeS AND Elections $159-80$ (1963) (discussing Condorcet's theory of elections). 
system of collective choice. ${ }^{8}$ Then he showed that no system can meet them all.

The conditions Arrow identified may be described as four conditions of fairness and a condition of rationality. These conditions, and the propensities associated with them, are reasonable and, on the face of it, mild: they generally preclude obviously perverse operations of a system of collective choice. 9 For instance, under these conditions a social choice is path imdependent; it cannot be influenced by means of agenda control. ${ }^{10}$

In the context of this article, a general discussion of the conditions of Arrow's theorem is unnecessary. The main point is that a systern of collective choice caunot simultaneously satisfy them all. As a point of interest, however, the conditions may briefly be described as follows. The first four conditions, as I said, are concerned with the fairness of a system of collective choice. The first of these is "unrestricted scope," which requires that a system of collective choice be able to process any coherent set of individual preferences as to any number of options. The second is one of "unanimity," which requires that when everyone prefers $A$ to $B$, a system must rank $A$ above $B$. The third is "independence of irrelevant alternatives." Under this condition, a social choice among options of a given set can depend only on preferences as to those options. The fourth condition, one that is a subject of this article, is that of nondictatorship-that no single individual can make his preference the social choice irrespective of the preferences of the other members of the community. ${ }^{11}$

The theorem's fifth condition, that of rationality, is of considerable interest to us. As identified by Arrow, this is a condition of transitivity. ${ }^{12}$ If $A$ is preferred to $B$, and $B$ to $C$, then these choices imply that $A$ is preferred to $C$. The converse is intransitivity, a decisional process that cycles, producing the unstable result of $A$ being preferred to $B, B$ to $C$, and then, irrationally, $C$ to $A$.

There is much to be said for transitivity as the measure of rationality in a system of collective choice. In rule-of-law terms, we sliould disfavor the instability and unpredictability, and the resulting drain on our pro-

8. See K. ARrow, supra note 1, at 24-31. Although these conditions may be essential to systems of collective choice, they are not sufficient. There may be other conditions that should be met. In our society, individual rights are such a condition; individual choices-speaking freely, for example-generally ought to prevail in the face of a collective preference to the contrary.

9. See A. Sen, Collective Choice and Social Welfare 36-40 (1979).

10. See K. ARRow, supra note 1 , at 120.

11. For an accessible discussion of the conditions of Arrow's theorem, see A. MACKAY, ARRow's THEOREM: THE ParadoX OF SOCIAL ChoICE 13-48 (1980).

12. K. ARRow, supra note 1 , at 13 . 
ductive capacities, that is created by intransitive social choices. The framers did. "What farmer or inanufacturer," they asked, will invest his capital or labor "when he can have no assurance that his preparatory labors and advances will not render him a victim to an inconstant government?"13 Intransitive social choices also implicate and infringe another, more moral, sense of government. When a political system by its laws sometimes prefer $A$ to $C$ and other times $C$ to $A$, how can we say that one choice is better than the other, and how can a particular choice command our respect?

In any event, taking this condition of rationality (transitivity) along with the four conditions of fairness, Arrow proved that no voting system can simultaneously meet them all, that if a voting system meets essential conditions of fairness, it cannot yield transitive (rational) choices. Thus, it may be thought that democratic methods are bound to produce unstable and chaotic social policy.

There is, however, a way of avoiding the impossibility of rational social policy shown by Arrow's theorem. That way is to relax the theorem's conditions of fairness. As one or more of these conditions is relaxed, rationality becomes possible. ${ }^{14}$ So it is that as a means of avoiding an inpossibility of rational social policy, relaxing Arrow's nondictatorslip condition is of some appeal, especially in light of existing political arrangements. Such a dictatorship is today established, in the person of bureaucrats, by open-ended delegations of legislative power to agencies.

This way out, however, runs liead on into Article I. That article provides that "all legislative power of the United States shall be vested in a Congress"15 and thereafter estabhishes a process for the exercise of that power. From the standpoint of Article I, the usual, and grave, objection to transferring legislative power to agencies is that such transfers are inconsistent witl consensual government as established by the electoral controls prescribed by Article I. The point liere, as I have mentioned, is that of ensuring "that the fundamental policy decisions in our society

13. The Federalist No. 62, at 421-22 (J. Madison) (J. Cooke ed. 1961). A modern affirmation of this rule-of-law value is found in E.I. DuPont de Nemours \& Co. v. FTC, 729 F.2d $128(2 \mathrm{~d}$ Cir. 1984). In this interesting case, the United States Court of Appeals for the Second Circuit attempted to confine the FTC's open-ended power with respect to "unfair methods of competition," 15 U.S.C. $\S 45$ (a) (1982), by acknowledging the need of the private sector to be able to predict government action as well as the duty of government to respond to this need. The court stated that "the Commission owes a duty to define the conditions under which conduct claimed to facilitate price uniformity would be unfair so that businesses will have an inkling as to what they can lawfully do rather than be left in a state of complete unpredictability." DuPont, 729 F.2d at 139. For further treatment of these concerns, see generally F. HAYEK, THE CONSTITUTION OF LIBERTY (1960).

14. See W. RIKER, supra note 6, at 136 ("The main thrust of Arrow's theorem and all the associated literature is that of an unresolved tension between logicality, [rationality,] and fairness.").

15. U.S. ConsT. art. I, $\S 1$. 
will be made not by an appointed official but by the body immediately responsible to the people." 16 Because the inconsistency of administrative lawinaking with consensual government is not an unmined subject, I will here ignore it. ${ }^{17}$ Instead, following leads suggested by Arrow's theorein, I will concentrate on matters of stability and circumspection in lawmaking and on how these matters show that rational social policy may be achieved within the frannework of Article I.

\section{A. The Decision Costs of Article I.}

It is no small irony to question Article I on grounds of instability. To the framers, looking back on the chaos under the Articles of Confederation, stability was essential to a good legislative process. A sense of this chaos, a sense similar to the the intransitivity identified by Arrow's theorem, is provided in Gordon Wood's account of laws "alteredrealtered-inade better-made worse; and kept in such a fluctuating position that people $\mathrm{m}$ civil commission scarce know what is law. [Laws] so profuse and coinplicated that ... the very means appointed to preserve order had become the source of irregularity and confusion."18

The reaction to this instability and a resolve to avoid it is set out in The Federalist No. 62. Here Madison describes, in rule-of-law terms, how such instability tended to "damp[] every useful undertaking" and how "no great improvement . . . can go forward, which requires the auspices of a steady system of national policy." 19 But worse than that was a moral impact such as I have already identified: the "diminution of attachment and reverence" toward a "political system" that lacked "a certain portion of order and stability."20

Formally, this "portion of order and stability" was to be instilled by the decision costs and checks of the legislative process created by Article

16. Arizona v. California, 373 U.S. 546, 626 (1963) (Harlan, J., dissenting).

17. I ain also ignoring in this article other important purposes of Article I, including those involving federalism, see, e.g., Wechsler, The Political Safeguards of Federalism: The Role of the States in the Composition and Selection of the National Government, 54 ColuM. L. REv. 543 (1954), and those obtaining to the developinent of a broad basis of information about proposed laws. See THE FEDERALIST No. 56, at 379-80 (J. Madison) (J. Cooke ed. 1961) (small nuinber of representatives will be able to convey the "knowledge" of each state).

18. G. Wood, Creation of the American Republic 405 (1969).

19. The Federalist No. 62, at 421-22 (J. Madison) (J. Cooke ed. 1961). Madison further explained that the rule of law is a barrier to "inconstant governinent":

What prudent merchant will hazard his fortunes in any new branch of coinmerce, when he knows not but that his plans may be rendered unlawful before they can be executed? What farmer or manufacturer, will lay himself out for the encouragement given to any particular cultivation or establishment, when he can have no assurance that his preparatory labors and advances will not render him a victim to an inconstant government?

Id.

20. Id. at 422 . 
I. ${ }^{21}$ How these costs and checks might do this can be explained by looking at the institutions-the House, the Senate, and the presidency-that are a part of the Article I process, and by looking at them first from without, and then froin within. Froin an external perspective, we may consider the House, the Senate, and the presidency as three separate 1nembers of a grand legislative committee established by Article I. As a matter of constitutional design, these institutions represent differing constituencies (the President a national constituency, the Senate and House varying degrees of local constituencies). Because they represent different constituencies with possibly differing preferences, treating them as separate voters seems reasonable. For these voters, the rule established by Article $I$ is that of unanimity; each committee nember may veto any option that it opposes. 22

Does Arrow's theorem show that it is inpossible for this committee to inake rational social choices? It does not. Without violating the theorein's conditions of fairness, the committee inay inake consistent and coherent choices. How this is so requires a further examination of the condition of rationality.

The condition of rationality is one of transitivity, and in this regard, transitivity as defined by Arrow requires that option $A$ be "as good as" option $B$. This "as good as" relation, lowever, itself subsumes two different relations: a voter inay either prefer $A$ to $B$, or he may be indifferent as between $A$ and $B$. Thus if a community is indifferent between $A$ and $B$, and between $B$ and $C$, then these choices imply that it is also indifferent as between $A$ and $C$. It seeins, however, that without any significant loss of rationality, transitivity can be dropped as to this second relation of indifference. For example, assume that $A, B$, and $C$ are jars of jelly beans, witl $A$ having one inore spoonful of jelly beans than $B$ and $B$ one more than $C$. It inay be that a community is indifferent as to adjacent jars on the jelly-bean scale, but not indifferent as to jars that are further (two spoons worth) apart. (A more global, though probably less

21. See id. at 421-22. The importance of Article I's decision costs was also emphasized in the crucial state ratification debates. James Wilson explained before the Pennsylvania convention that "the most useful restraint upon the legislature ... arises from the division of its power among two branches, and from the qualified negative of the President upon both." 2 THE DEBATES IN THE Several State Conventions on tHe Adoption of the Federal Constitution 446 (J. Elliot ed. 1836) [hereinafter Ellior's Debates]. Also, the Supreme Court has come to recognize the stabilizing effect of the bicameralism and checks of Article I: "The bicameral requirement, the Presentment Clauses, the President's veto, and Congress' power to override a veto were intended to erect enduring checks on each Branch and to protect the people from the improvident exercise of power..." INS v. Chadha, 462 U.S. 919, 957 (1983).

22. The President does not formally have an absolute veto; when he vetoes a bill, he ups the voting rule within each house to a two-thirds majority. The effect, however, is usually that of defeating the bill, and so we say that the President has a veto. 
reliable, illustration of collective indifference may be offered by choices among social states of disarmament, cold war, and hot war. Here, while persons might not distinguish between adjacent social states, they should certainly distinguish between states further apart.)

The phenomenon of intransitive indifferences, therefore, seens to "reflect the inability of individuals to distinguish among alternatives that are close together." ${ }^{23}$ We may, therefore, disregard it, and with virtually undimimished rationality require transitivity only with respect to "strict preferences," that is, where one option is perceived as better than the other. An ordering according to strict preferences is known as quasi transitivity. ${ }^{24}$

Importantly, this condition of quasi transitivity, with its virtually undimimished rationality, still conforins to the conditions of Arrow's theorein. ${ }^{25}$ That is, with rationahity defined as an ordering according to strict preferences, the fairness conditions of Arrow's theorem can be met. Moreover, with quasi transitivity, the choices made remam path independent; they are not susceptible to inanipulation by means of agenda control. ${ }^{26}$

A quasi-transitive system does, however, have some features that may not be attractive. It miphes an ohgarchy; persons within a community will be able to block (veto) preferences opposed to their own. ${ }^{27}$ (Quasi transitivity does not, however, imply a dictator. No person need be able to impose his own preferences on the rest of society.) Because quasi transitivity implies an oligarchy, it imphies a system that is (1) less egalitarian (the vote of persons with a veto counts more), and (2) less decisive (where one or more persons can block the choice of a majority of the community, the community simply camiot make as many choices). Therefore, in such a system, attention should be paid to where power lies (who has a veto) and to the facility with which it is exercised. Mindful of these concerns, the framers established an oligarchy of institutions-the "legislative coinmittee" consisting of the House, the Senate, and the President-that reifies the national legislative processes so as to make rational social choices possible.

In the legislative committee that these imstitutions comprise, the minimum set of preferences sufficient for making a choice (law) consists

23. Blair \& Pollak, Rational Collective Choice, ScI. AM., Aug. 1983, at 88, 91.

24. For discussions of the condition of quasi transitivity, see W. RIKER, supra note 6, at 130-36 (1982); A. SEN, supra note 9, at 15, 49; and Blair \& Pollak, supra note 23, at 89-93.

25. For proofs and explanations regarding how a quasi-transitive process meets the fairness conditions of Arrow's theorem, see A. SEN, supra note 9, at 52-55.

26. See id. at 48-49.

27. See id. at 49-50; Blair \& Pollak, supra note 23, at 91. 
of the preferences of one member plus at least the indifference of the other two. (Any opposed preference will result in a veto.) With such a minimum winning set, the preference of the whole committee is "strict." (When one prefers and all others are indifferent, a group is not indifferent.) Consequently, the decisional process of such a coninittee results in an ordering of strict preferences, and thus it is quasi-transitive. In this way, Article I, aniong both houses of Congress and the President, creates a decisional process that can yield consistent and coherent choices without sacrificing fairness.

Having examined Article I from solnething of an external view, I shall now move to within, to the internal decisional processes of each house of Congress. Froin this perspective, it can be seen that by means of decision costs within each house, the transitivity condition of Arrow's theorein is relaxed another degree, this time to a condition of "acyclity." For present purposes it seems sufficient to say that acyclity, while it is a somewhat weaker condition than quasi transitivity, is still a condition of stability: it is an absence of cycles in a relation of strict collective preference. ${ }^{28}$ Acychty, and its condition of stability, is induced by voting rules that require supermajorities. ${ }^{29}$ Such a voting rule seenis induced by the bicameratism of Article I.

On its face, Article I requires a sinple majority vote in both houses. But as Professors Tulloch and Buchanan have explained, that is not the effect of Article I. Given that members of the House and Senate represent different constituencies and given that these bodies must concur on a proposed law, a supermajority-in each house-is in effect required for much of the legislation approved by Congress. ${ }^{30}$ As such a supermajority is induced by bicameralisn, so is acyclity and a "portion" of the "order and stability" that the framers prized.

Formally, at two levels-the quasi transitivity established by its system of checks and the acyclity produced by its bicameralism-Article I establishes a decisional process that, as it rnles out cyclical majorities, inclines toward rationahty. Thus it is that Arrow's theorem is not an

28. See A. SEN, supra note 9, at 15-16; Blair \& Pollak, supra note 23, at 92-93.

29. The way in which supermajorities preclude cycling may be illustrated by the following example. If there are only two voters, $A$ and $B$, and two alternative choices, $X$ and $Y$, then cycling is impossible even under pure majority mle because it would require $A$ to prefer $X$ over $Y$ and $Y$ over $X$. Sane persons do not do that. If we increase the number of voters to five and the number of alternatives to three, under pure majority rule cycling is inevitable. But if we change the voting rule to that of a supermajority of four, cycling is impossible, for reasons similar to those pertaining to the two-voter, two-alternative situation (one of the four voters would have to vote contrary to his preference in order to produce a cycle).

30. J. Buchanan \& G. Tullock, The Calculus of Consent 232-48 (1962). See also P. Aranson, American Government: Strategy and Choice 367-69 (1981). 
impossibility theorem for Article I. Nonetheless, for Article I, the theorem remains supremely important. With precision it shows the studied way in which Article I makes rationality possible. At the same time, the theorem provides a basis for identifying a purpose of Article I im addition to that of rationality. This purpose is the "circumspection in lawmaking" to which I have previously referred and to which I now turn.

\section{B. The Indecisiveness of Article I and a Regard for a Private Ordering.}

The notion of a "democratic paralysis," a failure to act due not to a desire for inaction but an mability to agree on the proper action, seems to me to deserve inuch further empirical, as well as theoretical, study. ${ }^{31}$

To return to a central theme, Arrow's theorem shows that, in systems of collective choice, we cannot have it all. As we gain in one place, we stand to lose in another. It should be no surprise, then, that public choice studies building upon Arrow's theoren show that as stability is induced in systems of collective choice, the "decisiveness" of those processes is diminished. ${ }^{32}$ "Decisive" here refers to the rate at which a system produces decisions. As the decision costs and checks of Article I induce stability, they decrease that rate. Thus, a lesser degree of decisiveness is ordained by Article I-such is the cost of consensus. To the framers, however, this diminished decisiveness-at least in the context of domestic lawmaking ${ }^{33}$ - was a bonus.

At the Pennsylvania ratification convention, James Wilson explained that the legislative process he had helped create instilled a "circumspection in forming the laws" so as to avoid one of government's worst products, an "maccurate and undigested code of laws." lated point was made by Madison in The Federalist No. 62. There, he explained that "the facility and excess of lawinaking seein to be the diseases to which our governments are inost hable." 35 So, by ineans of the decision costs and checks of Article I, the frainers sought to curb this "facility and excess of lawmaking." As they did so, they explained that the "injury which may possibly be done by defeating a few good laws will be amply compensated by the advantage of preventing a nuinber of bad ones." 36

31. K. ARRow, supra note 1 , at 120.

32. See, e.g., Blair \& Pollak, supra note 23, at 95.

33. Whether an indecisive lawmaking process is equally desirable in the context of foreign affairs or in areas such as the budget, where a decision has to be made each year, is another question.

34. 2 Elliot's DeBATES, supra note 21 , at 447.

35. The Federalist No. 62, at 417 (J. Madison) (J. Cooke ed. 1961).

36. Id. No. 73 , at 496 . 
Undoubtedly, many proposed programs would never clear Congress if that body had to reach agreement with respect to their substance. Along with "politics" (the hazard to elected officials of hard choices among competing interests), an inclioate state of knowledge, scientific or social, may preclude agreement. In these circumstances-an absence of agreement among lawmakers as to an alleged problein and its solutiongovernment interference with a privately ordered society will tend to be ill-advised and premature. ${ }^{37}$

Still, Article I does not regard a private ordering of society as inviolate. It does, lowever, require that defects im this ordering, and a remedy for them, be carefully identified before government upsets it. Only then is the level of agreement required by Article I likely to be met. The legislative process established by Article I is therefore appropriately described as "calculated over time to minimize the costs of market failure and political failure." 38

To carry this notion further, consider Arrow's observation that "[i]n any historically given situation there is a social state which has a preferred status in social choice in that it will be adopted in the absence of a specified decision to the contrary." 39 If this is so, the "indecisiveness" of Article I does not signify a failed process or a failure to reach a choice. Rather, it means presumptively that choice is the status quo. And in the society that the Constitution serves, the status quo is largely that of free and uncoerced private arrangements.

37. As stated in the Senate's "Study on Federal Regulation":

Simply because a problem exists and, in theory is remediable, does not mean that regulation or other government intervention is desirable. Controls should only be undertaken where there is a clearly identified problem that cannot otherwise be solved, and where the anticipated achievements are significant and not vitiated by projected adverse consequences.

Senate Comm. on Governmental Affairs, Study on Federal Regulation, S. Doc. No. 13, 96th Cong., 1st Sess. xi (1978). See also The Regulatory Reform Act, S. Rep. No. 284, 97th Cong., 1st Sess. 14-17 (1981) [hereinafter The ReForm ACT]; A. SCHLESINGer, THe CyCLE OF AMERICAN HISTORY 311 (1986) ("When the country is not sure what ought to be done, the delay, debate and further consideration enjoined by the separation of powers are not a bad idea.").

38. Michelman, Politics and Values, 13 Creighton L. Rev. 487, 494-95 (1979).

39. K. ARRow, supra note 1, at 119. Arrow further explained this presumption for the status quo in the following manner:

Suppose that social state $x$ obtains when the environment is $S$. Now suppose that there is an innovation, so that the environment expands. In a basically free enterprise economy there will be an adaptation which is controlled by property laws and the workings of the system. The resulting social state, say $x_{l}$, which in general differs from $x$, will automatiId. cally prevail unless there is a specific legislative decision to alter it. 


\section{Agency Rationality AND CiRCumSPection}

As I said at the outset, the delegation of legislative power to agencies is usually seen as a trade-off of democratic values for the greater rationality and decisiveness of agencies. But because this view assumes that rationahity is in fact served by administrative lawmaking and because it fails to question the desirability of greater decisiveness, I think it is too narrow. Consequently, I will now extend the inquiry to consider whether open-ended delegations of legislative power to agencies comport with Article I's purposes of rationality and circumspection in lawmaking.

\section{A. Positive Government and Indecisiveness.}

Rather than being seen as inducing a healthy tendency toward circumspection in government, the decision costs and checks of Article I have come to be seen as creating an unfortunate tendency toward deadlock in government. Undoubtedly, this disaffection has been an aspect of a faith in positive government that grew with the New Deal, a faith seen in Felix Frankfurter's endorseinent of the following proposition:

The way to realize a purpose is, not to leave it to chance, but to keep it loyally in mind and adopt means proper to the importance and the difficulty of the task. No voluntary association of individuals, resourceful and disinterested though they be, is competent to assume the responsibility. The problein belongs to the American national democracy, and its solution must be atternpted chiefly by means of official national action. ${ }^{40}$

If an assertion of government power-"official national action"-is presumptively good, then encumbrances on this power are bad, and the worst of these encumbrances are the decision costs and checks of Article I. Institutional arrangenents that transmit government power away from these costs are therefore favored. Of these arrangements, the most prominent is that of transferring, or delegating, legislative power to adininistrative agencies. These delegations as they deliver power en gross, unharnessed and unchecked, are, as Professor Jaffee has said, truly the "dynamo of the modern social services state." 41

Faith in positive government has operated at several levels to create and accommodate this dynamo. It has operated in Congress, contributing to what is known as a "regulatory lottery."42 Legislators, believing that government ought to take action but unable in Congress to achieve

40. F. Frankfurter, Law and Politics 308 (1939) (quoting H. Croly, The Promise of AMERICAN LIFE (1909)).

41. Jaffe, An Essay on Delegation of Legislative Power: II, 47 CoLuM. L. REv. 561,592 (1947).

42. Aranson, Gellhorn \& Robinson, $A$ Theory of Legislative Delegation, 68 CORNELL L. REv. $1,60-61$ (1982). 
agreement as to the rudiments of that action, make action in some form possible by an open-ended delegation of legislative power to an agency. Their hope is that the action the agency takes will, by the legislators' own lights, turn out to be good. ${ }^{43}$

This lottery does not necessarily or even usually render the problem more tractable or move it closer to a good solution. In our political system, agencies, when left to make basic policy decisions, generally do not seem to arrive at these decisions im the rational, scientific way that scholars had predicted. ${ }^{44}$ Also, the agency does not necessarily have information or access to information about these choices that is denied to Congress. The one thing that passing a problem to an agency can confidently be counted on to do, however, is to bring that problem closer to a solution. The agency, with a more narrow sense of mission and fewer decision costs, will usually succumb to the endurmg compulsion of agencies: it will proceed to regulate, even with a significant risk of being wrong. 45

A classic description of the regulatory lottery is provided by the following exuberant account of the creation of the Civil Aeronautics Board (the $\mathrm{CAB}$ ):

There will of course be occasions when Congress cannot make wise decisions because experience with the substantive areas under consideration is too limited and the policy questions that must be answered are still too indistinct to permit responsible lawmaking. This was surely the case, for example, when Congress passed the Civil Aeronautics Act of 1938. In such cases, broad delegations of legislative power to administrative agencies are essential if effective governinent action is to be taken at all. ${ }^{46}$

43. In this regard, as lawyers know, legislative histories show varying expectations in that lottery, and therefore commonly support mutually inconsistent courses of action.

44. See supra note 4 and accompanying text.

45. See Subcomm. on Admin. Practice and Procedure of the Senate Comm. on the Judiciary, 94TH CONG., Ist Sess., Report on Civil Aeronautics BoARd Practice AND ProCEDURE 20 (Comm. Print 1975) [hereinafter REPORT] ("[T] he classical regulatory response to defects in regulation is to create more regulation."). A similar observation about agency bias toward "doing something" has been made with reference to the Consumer Products Safety Commission:

The CPSC is not in charge of keeping down the cost of living, or saving people an ounce of inconvenience, or maximizing freedom of choice (even though officials do take such factors into consideration). The CPSC is in the business of reducing injury from consumer products, and it is hardly surprising that its bias is towards taking measures which promotc that goal, even when they have attendant costs.

Kelman, Regulation by the Numbers-A Report on the Consumer Products Safety Commission, 36 Pub. INTEREST 83, 90-91 (1974). As explained by Professor Jaffe, the agencies are not so much industry-oriented or consumer-oriented as they are regulation-oriented: they are in the regulation business, and regulate they will. Jaffe, The Effective Limits of the Administrative Process: A Reevalu. ation, 67 HARV. L. REV. 1105, 1113-19 (1954).

46. See J. Freedman, Crisis and Legitimacy: The Administrative Process and AMERICAN GOVERNMENT 93-94 (1978). 
The issues too "indistinct" for congressional resolution were largely economic issues such as whether only a few major airlines should be proinoted, whether local air service to sinaller communities should be promoted, and so on. Over the years, the CAB was criticized for its own failure to develop firm policies with respect to these inatters. But the $\mathrm{CAB}$ did of course act consistently in one direction: it persistently chose governinent control and regulation as the general solution to airline problems. Today, of course, this solution has been determined to be a bad one, and by a process of "deregulation" it has been undone. ${ }^{47}$

The example of the CAB illustrates the problem - an unacceptable risk that government regulation will be inferior to uncoerced private arrangements-that results from bypassing the constraints of Article I. Studies forming the backbone of the deregulation movement have provided a more systematic examination of whether broad scale transfers of legislative power to agencies create such a problem. Generally, the fields for deregulation identified by these studies tend to be occupied by agencies to which Congress has open-endedly transferred its legislative power. ${ }^{48}$

\section{B. Agency Rationality.}

The capacity of agencies, operating according to principles of technocratic governance, to produce consistent and coherent social policy is the long-standing raison d'être of the administrative state. For a couple of reasons, however, agencies, at least in our political systein, can be expected to fall short of this rationality standard.

What is probably the lesser reason pertains to the common "commission" structure of admmistrative agencies. This structure is that of an agency headed by:a multimeinber body, with agency action ordained by a majority vote of that body. This sort of decisional process, committee voting by means of majority rule, is the very process for which Arrow's theorem shows the impossibility of rational social choice. It cannot, therefore, be presuned to be capable of developing consistent and coherent social policy. ${ }^{49}$

47. See Airline Deregulation Act, Pub. L. No. 95-504, 92 Stat. 1744 (1978) (codified in scattered sections of 49 U.S.C.).

48. See, e.g., REPORT, supra note 45, at 19; Peck, Competitive Policy for Transportation, in THE Crisis of the Regulatory Commissions 77-78, 89 (P. MacAvoy ed. 1970); Fowler \& Brenner, $A$ Marketplace Approach to Broadcast Regulation, 60 TEX. L. REV. 207, 256 (1981).

49. In an analysis premised on Arrow's theorem, Professor Easterbrook has suggested that a similar institutional defect plagues another multimember body governed by pure majority rule-the Supreme Court. See Easterbrook, Ways of Criticizing the Court, 95 HARv. L. REv. 802, 823-31 (1982). 
In the context of a commission voting according to majority rule, consistent voting results can, however, be induced by means of a condition known as "single peakedness." Single peakedness refers to a homogeneity of basic values within a voting group. With it, rational social choice is possible - even in the case of an institution operating according to pure inajority rule. 50 Congress may induce homogeneity in agencies and the commissions that head them, but to do so Congress must forgo open-ended delegations of legislative power to those agencies. Congress itself inust inake basic policy clioices and provide the agencies with standards and marching orders respecting those choices. These directions froin Congress, by narrowing the range of values that the agency may choose from, should induce the lomogeneity essential to rational regulation.

Anotler ineans of avoiding inconsistent social choices by commissions is to eliminate commissions, and to place each agency under the control of a single person. But that action would probably not work eitler, for reasons pertaining to the nature of our pohitical system. In our system, bureaucratic planners do not occupy the removed and disinterested positions that scholars have soinetimes presumed. Without objective and scientific measures of the "public interest" to bolster thein, ${ }^{51}$ without an anclior in the Constitution, and without ratification of their clioices by ineans of the ballot box, agency officials can and will be set upon by individual congressinen or congressional cominittees, by the White House, by the courts, and by interest groups. Subject to these pressures, agencies twist and turn, and indeterminate and fluctuating policy is often the result. 52

The rougli liypothesis that I am trying to establish is that openended delegations of legislative power to agencies contribute to an insti-

50. See D. BLACK, supra note 7, at 14.

51. The customary justification for committing social policy to experts involves a concept of lawmaking according to clean scientific truths, divined by experts, as would lift it out of the infirm muck of politics. This idea of scientifically determined social policy is, however, flawed. Insofar as basic choices of social policy are concerned, there is usually no objectively determinable scientific truth sufficient to guide and bolster the expert planner. Science might, for example, be able to rclate the health of workers to certain types and quantities of carcinogens. But the larger question-which levels of carcinogens best serves the interest of these workers as well as the interest of the rest of society-involves trade-offs with aggregated personal preferences about safety, risk acceptance, wages, productivity, and inflation. In weighing these primary choices among conflicting personal preferences, "technical experts have no special claim to wisdom," S. BREYER \& R. STEWART, ADMINISTRATIVE LAW AND REgulAtORY POLICY 128 (1985), and they are not "institutionally capable of making the basic value choices." THE REFORM ACT, supra note 37, at 59.

52. A thorough study and explanation of the failure, indeed the inability, of agencies to themselves develop consistent social policy is provided by T. LowI, THE END OF LIBERALISM: IDEOLogy, Policy, AND the Crisis of Public Authority (1969). See also The Reform Act, supra note 37 , at 59 . 
tutional neurosis that makes rational regulation unlikely, if not impossible. If, however, Congress itself resolves major policy issues and sets basic standards, then the agency official has a politically secure framework in which expertise can be apphed so as to make rational social choices possible and perhaps even likely.

This hypothesis is supported by agency practice. Those agencies of higher regard in terms of their coherency, stability, and professionalism are generally those agencies that were created after Congress had with care identified a defect in private orderings and then worked out the rudiments of repair. These agencies should include the Environmental Protection Agency, the Securities Exchange Commission, and the Social Security Administration. ${ }^{53}$ The regard for these agencies should be contrasted to a general disappointment with the rationalism of agencies of inore open-ended delegations, where there was never agreeinent in Congress either as to the defects in a private ordering or a cure. These agencies should include the Civil Aeronautics Board, the Federal Commumications Commission, the Federal Trade Commission, and the Occupational Safety and Health Administration. ${ }^{54}$

53. For studies attesting to the fact that in the case of these agencies Congress carried out its primary task of identifying social problems and provided the agencies with the rudinents of solutions to those probleins, see M. Derthick, Policymaking for Social Security 21, 46 (1979); and Cohen, Federal Legislation Affecting the Public Offering of Securities, 28 GEO. WASH. L. REV. 119,156 (1959). With respect to the EPA, the statutory mandate under which it operates has been described by the Supreine Court as a "lengthy, detailed, technical, complex, and coinprehensive response to a major social issue." Chevron U.S.A., Inc. v. Natural Resources Defense Council, 467 U.S. 837, 848 (1984). In inplenenting this prograin, the EPA has been credited with doing a generally professional job. See, e.g., Marcus, Environmental Protection Agency, in THE Polirics of REgULATION 267, 300-01 (J. Wilson ed. 1980). One criticisin of the EPA's statutory mandate is that the standards were perhaps too stringent. Without coinpromising the general requirement of standards, those particular standards might have been soinewhat less stringent so as to allow the EPA more flexibility in a quickly developing technology. See B. ACKERMAN \& W. Hassler, CLEAN COAL/ DIRTY AIR 56-57 (1981).

54. Bad reviews of the work of these agencies are not in short supply. A typical review of OSHA is that "[b]oth politically and practically [OSHA] has been a failure. It has generated flerce antagonism in the business coinununity and is viewed as the quintessential government intrusion. And it has had virtually no noticeable inpact on work related injuries and illnesses." Nichols \& Zeckhauser, Government Comes to the Workplace: An Assessment of OSHA, 49 PUB. INTEREST 39, 42 (1977). OSHA operates under an open-ended "safe and healthful working conditions" form of delegation. Occupational Safety and Health Act of 1970, § 2(b), 29 U.S.C. § 651(b) (1982). For a review of the work of the FTC, see generally THE FEDERAL TRADE COMMISSION SINCE 1970: Economic Regulation and Bureaucratic Behavior (K. Clarkson \& T. Muris eds. 1981); Posner, The Federal Trade Commission, 37 U. CHI. L. REv. 47 (1969). For a comprehensive study of the failure of agencies with broad delegations of authority to develop policy and theory, see $T$. Loivi, supra note 52.

Support for the general thesis that agencies perform better when Congress itself carefully identifies a problein and provides at least the rudiments of a reinedy is provided by the following comparison of the National Labor Relations Board with New Deal agencies that failed: 


\section{The Delegation Doctrine}

To this point, I have examined a certain first impression about Arrow's theorem and democratic politics: that rational social policy is impossible within the zone of democratic politics created by Article I of the Constitution, and that therefore we should escape that zone to areas where such rationality is possible. The modern administrative agency is thought to be such a place, because it is thought to operate according to a condition of dictatorship that makes rationality possible.

This whole impression, however, seems wrong. It seems wrong inasmuch as Article I mitigates the idea of straight-out democratic politics-the simple idea of majoritarian rule-for which Arrow's theorem shows an impossibility of rational social choice. Article I mitigates this idea of majoritarian rule by means of an elaborate system of decision costs and checks which, in techrical terms of quasi transitivity and acyclity, make rationality possible--and indeed enhance it. What might be considered a cost of this mitigation is a loss of decisiveness in the system. The framers, however, turned this "cost" around. They used it to diminish the risk of government regulation that turns out to be inferior to private and uncoerced social and economic choices.

The impression about Arrow's theorem and Article I also seems wrong as it pertains to achieving rationality through bureaucratic processes. Considering the common commission form of administrative agencies and, more importantly, considering the generally politically insecure framework of these agencies, the rationality that has been expected of them, at least where they are the unfortunate recipients of open-ended delegations of legislative power, has not been forthcoming.

So what are we to make of these things? It is that as a matter of constitutional principle (a principle drawn from Article I, its purposes of rationality and circumspection, and its more commonly expressed purpose of consensual government), "important choices of social policy"ss should be made in Congress and not in the agencies. This principle should first of all be followed in Congress, and today that seems to be the case. There is evidence that Congress has abandoned its past practice of weak-kneed "go forth and do good" types of delegations, and is instead

[T] he Wagner Act was a skillfully drafted statute adopted after two years of revision and

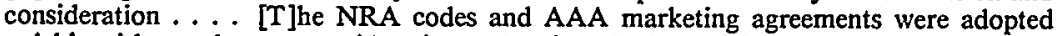
quickly without adequate consideration and review. In fact, both the NRA and AAA were dubious products of political expediency. If Congress had acted with greater care and less unthinking haste, each agency might have proven less vulnerable constitutionally.

Teaford, A Plague of Young Lawyers: Irons on The New Deal Lawyers, 1983 AM. B. Found. Res. J. 966, 969.

55. Industrial Union Dep't v. American Petroleum Inst., 448 U.S. 607, 685 (1980) (Rehnquist, J., concurring). 
providing primary standards to guide and contam agency power. ${ }^{56}$

The question that remains, however, and the question that I wish to address $\mathrm{m}$ this final Part, is whether this principle-that important choices of social policy should be made in Congress-should and can amount to a legal right. Should and can a private party expect the courts to require that Congress make these choices?57 In the courts, such a right, as it is grounded in the purposes of Article I, seems to have received the Supreme Court's endorsement in its famous "legislative veto" case. ${ }^{58}$ In that case the Court acknowledged that Article I is a "single, finely wrought and exhaustively considered, procedure" 59 and invited a strict attention - on the part of the courts-to maintaining that process.

The legal right pertinent to ensuring that Congress makes important social policy choices is encapsulated in the well-known "delegation doctrine." By this doctrine, the courts, on the petition of private parties, are supposed to ensure that primary legislative power remains in Congress. In this form, the doctrine acknowledges that a secondary degree of lawmaking power may be usefully and lawfully delegated to agencies. The reasons why such delegations are appropriate may be quickly summarized. To start with, and as explained by Thomas Jefferson, the resources of Congress may be usefully conserved by avoiding the diversion of that body "from great to sinall objects." 60 At the same time, agencies with their lower decision costs are often better at working through "a labyrinth of detail."61 The lower decision costs of agencies also make possible an adaptability that forms another reason for the delegation. By first establishing primary standards, and then delegating a secondary lawmaking authority to agencies, Congress can create a useful flexibility in the face of changing circumstances-a flexibility that is perhaps inost useful where technology is rapidly developing, as in the area of environmental

56. For discussions of the revived congressional interest in tighter delegations, see E. BARDACH \& R. KAGAN, GoING BY THE Book 46-49 (1982); and Marcus, supra note 53, at 267-74. See also ThE REForm ACT, supra note 37, at 172-73; McGowan, Congress, Court, and Control of Delegated Power, 77 Colum. L. REv. 1119, 1130 n.44, 1132 n.47 (1977). For recent examples of the practice of tighter delegation, see the Railroad Revitalization and Regulatory Reform Act of 1976, Pub. L. No. 94-210, 90 Stat. 31 (codified as amended in scattered sections of 15, 31, 45 \& 49 U.S.C.); the Staggers Rail Act of 1980, Pub. L. No. 96-448, 94 Stat. 1895 (codified as amended in scattered sections of 11, 45 \& 49 U.S.C.); and the Long-Cannon Amendment, 49 U.S.C.A. $\$ 10707 a(e)(2)(A)$ (West Supp. 1986).

57. Since legislators may for self-serving reasons seek to give up their legislative power, see Aranson, Gellhorn \& Robinson, supra note 42, at 56-62, the check of judicial review seems especially necessary in order to keep that power in Congress and out of the agencies.

58. INS v. Chadha, 462 U.S. 919 (1983).

59. Id. at 951.

60. 4 The Writings of Thomas Jefrerson 424-25 (P. Ford ed. 1894).

61. J. LANDIS, supra note 4 , at 70. 
controls. ${ }^{62}$

So, yes, while "important choices of social policy" ought to be made in Congress, at the same time some delegation of secondary legislative power seems useful if not essential. The problem that bothers many scholars, however, is this: How are the courts to distinguish between a nondelegable primary power and a delegable secondary power? In one important context, this problem is avoided because the delegation doctrine, properly construed, simply does not require the courts to make this kind of distinction. In this context, the courts stand as a barrier to the common bureaucratic tendency to aggrandize power. An excellent example is provided by a case decided by the United States Court of Appeals for the Fifth Circuit, in which the Interstate Commerce Commission, by ineans of its own selective reading of its statutory charter, ignored the charter's several standards that defined and confined its power. ${ }^{63}$ Instead, the ICC tried to expand its power by fastening on such expansive and open-ended phrases as inight be found in its charter. On the basis of this parsing of its statutory authority, the Commission claimed that it had been broadly delegated the power to implement a "national transportation policy." 64

The Fifth Circuit, however, held that the Coininission's power was not to be ineasured by vague and general phrases found in its charter. "Such a reading," the court said, "would inake superfluous inuch of the rest of the Revised Interstate Cominerce Act, with its detailed guidelines and delegations of authority."65 Moreover, the court warned that "construmg the National Transportation Policy, which paraphrased says little inore than 'go forth and do good,' as a congressional grant of rulemaking authority might well amount to an unconstitutional delegation of legislative authority." 66

Still the question remams. What if Congress oversteps, and lets go of its primary legislative power? Is that an event that the courts can discern and check? Consistently, through all the ups and downs of the delegation doctrine, the courts have mamtained that they can. ${ }^{67}$ They

62. See Chevron U.S.A., Inc. v. Natural Resources Defense Council, 467 U.S. 837, 863.64 (1984) ("[T]he agency, to engage in informed rulemaking, must consider varying interpretations and the wisdom of its policy on a continuing basis.").

63. Central Forwarding, Inc. v. ICC, 698 F.2d 1266, 1279-83 (5th Cir. 1983). See also Global Van Lines, Inc. v. ICC, 714 F.2d 1290 (5th Cir. 1983).

64. Central Forwarding, 698 F.2d at 1283.

65. Id. at 1284 .

66. Id.

67. See, e.g., National Cable Television Ass'n v. United States, 415 U.S. 336, $340-41$ (1974); A.L.A. Schechter Poultry Corp. v. United States, 295 U.S. 495, 529 (1935); Wayman v. Southard, 23 U.S. (10 Wheat.) 1, 42-50 (1825). The link between a requirement of standards and the delegation doctrine is longstanding. James Madison explained: "If nothing more were required, in exercising a 
say that they can do so by means of a requirement of standards, and given a reasonably clear idea of what a standard is, I think that they are right.

In this context, the term "standard" should be thought of in its traditional sense of a statement of a limited range of "exclusively relevant values." 68 Under this definition, agencies may not be left free to choose from an unlimited range of values, as is the case with delegations of the "public interest" variety. 69 And under this definition, the courts have indeed been able to discern whether an agency has been left free to choose among values "in the manner of" a legislative body.

In a inajor delegation doctrine case, Panama Refining Co. v. Ryan, ${ }^{70}$ the Supreme Court was concerned with a delegation of authority to prohibit the transportation of "hot oil" among the states. ${ }^{71}$ Addressing the validity of that delegation, Chief Justice Hughes, writing for the Court, defined the Court's role as that of "look[ing] to the statute" to see whether Congress had "set up a standard."72 And here Congress, as the Court was able to discern, had not done so. Congress had, to be sure, provided an extensive statement of purposes, such as proinoting cooperative action among imdustrial groups, eliminating unfair competitive practices, inducing labor-management unity, promoting the fullest utilization of existing productive capacity, reducing unemployment, and so forth. ${ }^{73}$ But im these "diverse objectives broadly stated," 74 Congress's failure to establish national policy was writ large. These were not standards; instead, they were simply a recital, without resolution, of the values and interests that had confronted Congress.

A more recent example of the viability of a court-enforced requirement of standards is provided by the Supreme Court's decision in $\mathrm{Na}$ tional Cable Television Association v. United States. ${ }^{75}$ In 1952, Congress had by statute authorized the agencies (particularly the Federal Communications Commission) to become "self-sustaining" by charging the pri-

legislative trust, than a general conveyance of authority-without laying down any precise rules by which the authority conveyed should be carried into effect-it would follow that the whole power of legislation might be transferred by the legislature from itself ...." 4 ELLIOT's DEBATES, supra note 21 , at 560 .

68. Soper, Legal Theory and the Obligation of a Judge: The Hart-Dworkin Dispute, 75 MiсH. L. REV. 473, 482 (1977).

69. As one court has said, "[t]he phrase 'public interest' is 'a concept without ascertainable criterion.'" Bell Tel. Co. v. Driscoll, 343 Pa. 109, 116, 21 A.2d 912, 915 (1941).

70. 293 U.S. 388 (1935).

71. Id. at 414-15.

72. Id. at 415 .

73. National Industrial Recovery Act, ch. 90, § 9(c), 48 Stat. 195, 200 (1933).

74. Panama Refining, 293 U.S. at 420.

75. 415 U.S. 336 (1974). 
vate sector for the value of regulatory benefits bestowed. ${ }^{76}$ Under this statute, the amount of the charge was to be calculated according to the "direct and indirect cost to the Government, value to the recipient, pubhic pohicy or interest served; and other pertinent facts."77 Pursuant to this provision, the Federal Communications Commission imposed a charge of $\$ 1,145,000$ on cable television systems. ${ }^{78}$

The plaintiff, a cable television trade association, argued that this charge was in fact a tax and thus an unconstitutional assumption of a legislative power reserved for Congress. That argument prevailed. ${ }^{79} \mathrm{In}$ finding for the plamtiff, the Court affirmed that as a matter of constitutional principle, "Congress is not permitted to abdicate or to transfer to others the essential legislative functions with which it is . . vested." 80 It apphed this principle by eliminating those portions of the Act that left the agency free to pick among competing values "in the manner of" a legislative body. In particular, the Court objected to the Act's "public policy or interest served" measure of charges, because that measure "if read literally, carries an agency far from its custoinary orbit and puts it in search of revenue in the inanner of an Appropriations Committee of the House."81 By eliminating these open-ended parts of the Act, the Court confined agency power to the deternminate "value to the recipient" portion. ${ }^{82}$

These cases show that the long-standing requirement of standards provides a ineasure sufficiently objective to enable the courts to ensure that primary choices of social policy are made in Congress rather than in the agencies. ${ }^{83}$ Once the threshold of standards is reached, however, the work of the courts is at an end. Thereafter, the degree of authority that Congress wishes to delegate is a decision that properly lies with Congress. ${ }^{84}$

76. Independent Offices Appropriation Act, Pub. L. No. 138, 65 Stat. 268 (1952) (codified as amended in scattered sections of $12,31,36,42,46,49 \& 50$ U.S.C.).

77. Id. tit. 5, 65 Stat. at 290 (current version at 31 U.S.C. $\$ 9701$ (1982)).

78. National Cable Television, 415 U.S. at 340.

79. Id. at 340-44.

80. Id. at 342 (quoting A.L.A. Schechter Poultry Corp. v. United States, 295 U.S. 495, 529 (1935)).

81. Id. at 341 .

82. Id.

83. The requirement of standards relates to keeping "important matters of social policy" in Congress; however, where such matters are not involved and the agency is not expected to develop broad social policy, it is not as essential to maintain primary legislative authority in Congress. In such cases, the requirement of standards is less stringently applied. See, e.g., Buttfield v. Stranahan, 192 U.S. 470, 496 (1904) (approving open-ended agency authority to grade quality of imported tea).

84. As the Supreme Court has stated:

[E]ach enactment must be considered to determine whether it states the purpose which the Congress seeks to accomplish and the standards by which that purpose is to be worked out 


\section{CONCLUSION}

As seen in the strong clear light of Arrow's theorem, a bottom line of Article I is that, as someone has said, "democracy is a systein for people who are not sure that they are right." That modesty ought not to be lost by replacing the constraints of Article I with the permissiveness of open-ended transfers of legislative power to agencies. In principle, the Supreme Court seems to agree, for in Bowsher v. Synar it explained that "the fact that a given law or procedure is efficient, convenient, and useful in facilitating functions of government, standing alone, will not save it if it is contrary to the Constitution. Convenience and efficiency are not the primary objectives-or the hallmarks-of democratic government." 85

Finally, I should say that the rationality and circumspection that I have identified as purposes of Article I are by no ineans fully realized in Congress: politics are not so perfectly harnessed. Nonetheless, in Congress these purposes should amount to continuities, and in that sense the delegation doctrime should avoid a retardation of theni.

with sufficient exactness to enable those affected to understand these limits. Within these tests Congress needs to specify only so far as is reasonably practicable.

United States v. Rock Royal Co-Op., 307 U.S. 533, 574 (1939). See also Industrial Union Dep't v. American Petroleum Inst., 448 U.S. 607, 685-86 (1980) (Rehnquist, J., concurring) (nondelegation doctrine guarantees that "to the extent Congress finds it necessary to delegate authority, it provides the recipient of that authority with an 'intelligible principle' to guide the exercise of the delegated discretion").

85. Bowsher v. Synar, 106 S. Cl. 3181, 3193-94 (1986) (quoting INS v. Chadha, 462 U.S. 919, 944 (1983)). 